\title{
Challenges of Kosovo Micro Businesses
}

\author{
Fehmi Krasniqi \\ MSc Business Administration, Public \\ University Ukshin Hoti Prizren, Kosovo \\ Hysni Terziu \\ Prof. Assoc. Dr, Public \\ University Ukshin Hoti Prizren, Kosovo
}

\section{Abstract}

The challenges that micro-businesses face during the lending process are numerous. Loans are with high-interest rates. There is a lack of loans with low-interest rates that would stimulate the growth of local businesses. On the one hand, the local business faces various trade barriers such as export in the regional market and EU countries, although Kosovo is a signatory to the CEFTA agreement. On the other hand, there is a lack of institutional support, which not only does not support the stimulation of exports but also within Kosovo makes the local business non-competitive about importers of goods. Interest rates are reduced to $2-3 \%$ on an annual basis. Increase the repayment period of loans (long-term loans) for capital investments. Allow the grace period at the beginning of the investment as well as have variable payments based on business income. Reduce bureaucracies when taking loans, reduce the demand for collateral by banks when taking loans. Reduce the business tax rate. Reduce unloyal competition and the informal economy that hurts local business. To stimulate start-up businesses, to support projects especially in the field of informatics. Start-up businesses are not so much supported by banks in Kosovo. Increase women's participation in business, through support, because they make up about $13 \%$ of businesses operating in Kosovo. It is intended that the participation of women in business will reach $50 \%$. Make greater support of micro-businesses because these businesses can grow and develop and employ a large number of employees. Microbusinesses in Kosovo make up about $98 \%$ of enterprises in Kosovo. Establish a development bank that would support local business and create better facilities and conditions for foreign investors.

Keywords: Kosovan micro-businesses, Start-up businesses, Women in business, Business support, Business empowerment, Kosovo guarantee fund, Kosovan business support 


\section{Introduction}

The challenges that micro-businesses face during the lending process are numerous. Loans are with high-interest rates. There is a lack of loans with low-interest rates that would stimulate the growth of local businesses. On the one hand, the local business faces various trade barriers such as export barriers in the regional market and in EU countries, although Kosovo is a signatory to the CEFTA agreement. On the other hand, there is a lack of institutional support, which not only does not support the stimulation of exports but also within Kosovo makes the local business noncompetitive in relation to importers of goods.

Barriers start from the very beginning of opening a business, a lot of documentation is required, there is a lot of bureaucracy, corruption and nepotism issues. Failure to create favourable investment conditions for foreign investors. This is confirmed by Kosovo's ranking in doing business. According to the analysis and criteria of the WB, Kosovo is ranked 117 th.

How convenient is the loan term? How appropriate are credit and fiscal policies? The impact of informal economy and unfair competition on the market. Is there institutional and other support for entrepreneurs? Is there any impact of credit policies on business development? How does the KGCF (Kosovo Credit Guarantee Fund) guarantee funds, which cover up to $50 \%$ of the amount credited in case of failure, been affected? How have credit policies affected the financing of business projects? Have banks had an impact on co-financing projects for entrepreneurs who have been winners of any government grants from government funds, EU funds, US Aid?

\section{Literature Overview}

"States can offer low taxes and levies or even land leased for a certain period, but if investors are afraid of civil unrest, expropriation of assets, labour revolts or inability to cope with natural disasters, health crises as in the current situation then they are discouraged and their goals are oriented to safer places " - Muhamet Hajrullahu1.

The Kosovar business community during 2017 reported as the biggest barrier "unfair competition from the gray economy" (61\%), followed by "cost and reliability in electricity" (51\%), high interest rates and other costs for banking transactions "(38\%)," lack of cash "meaning delays in payments by consumers (32.5\%) and" lack of skilled labor"(31.6\%).

${ }^{1}$ Muhamet Ajrullahu, Challenges of doing Business in Kosovo, Rajoni Press, Gjilan 2020. 
On the one hand infrastructure, barriers have the main place among the top barriers, with special emphasis on the cost and reliability of electricity (51.1\%). Political instability (37.8\%) also ranks among the main barriers in this category, which as such has been proven based on other reports published by KCC, such as the "Business Climate Index" that in periods when our country has political instability the confidence of businesses falls. On the other hand, corruption (28.5\%), in 2017 was considered as one of the main barriers for Kosovo businesses ${ }^{1}$.

Kosovo continues to be one of the most unsuitable countries in the world to do business due to long procedures and delays and many other complications from the first steps of opening (registering) a business but also later during the existence of it.

This is due to the large number of documentation required by laws and acts in force and also due to numerous delays in their processing and implementation by institutions and local administration from the central to the local level.

Such a conclusion can be made based on the latest report of the World Bank (WB) for 2012, "Doing Business in Eastern Europe". Again as last year, Kosovo according to the analysis and criteria of the WB is ranked 117th place to do business².

\section{Materials and Methods}

The main data used in the compilation of this paper are based on scientific and professional literature from the field of economics. The paper is based on research conducted by local and international institutes, where interest rates have an important role in raising revenues at the national level. Based on the level of interest rates, economic development is also stimulated.

The methods used for research are analytical, statistical, comparative, descriptive, and historical (empirical) methods.

The survey includes age groups from 25 to 66 years and both genders. The total number of respondents is 77 . The purpose of this survey was to identify the challenges faced by local businesses. Is there a bureaucracy? Is it too much collateral required by banks?

During the drafting of this paper, the data will be processed, and the variables used to validate the hypotheses will be compared. Data from many articles and publications will also be collected.

\section{Businesses in Kosovo}

According to ARBK, the number of NVMs registered on December 31, 2010, was sizeable than 100,000 , which employs 216,799 workers, or more precisely $79.59 \%$ of

\footnotetext{
${ }^{1}$ Kosovo Chamber of Commerce, Paving the way for better business in Kosovo, Prishtinë, 2018. ${ }^{2}$ Arbër Berisha, The Challenges of opening and maintaining a functioning business, Ekonomia, Prishtinë, 2021.
} 
the total number of employees in the private sector and with a total number of $62.24 \%$ in Kosovo.

Table 1.Enterprises Registered in Kosovo by Number of Employees - 2010

\begin{tabular}{|l|l|l|l|}
\hline $\begin{array}{l}\text { Classification by } \\
\text { size }\end{array}$ & $\begin{array}{l}\text { Number of } \\
\text { workers }\end{array}$ & $\begin{array}{l}\text { Number of } \\
\text { enterprises }\end{array}$ & Percentage in total \\
\hline Micro & $1-9$ & 102,070 & 98,37 \\
\hline Small & $10-49$ & 1,406 & 1.35 \\
\hline Medium & $50-249$ & 221 & 0.22 \\
\hline Large & $250+$ & 58 & 0.06 \\
\hline In Total & & 103,755 & 100.00 \\
\hline \multicolumn{3}{|l}{} \\
\hline
\end{tabular}

Out of a total of 103,755 enterprises: 102,070 (or 98.37\%) are micro-enterprises; $1,406(1.35 \%)$ are small; $221(0.22 \%)$ are medium and only $58(0.06 \%)$ are classified as large. The large dominance of micro-enterprises has implications for the NVM Strategy Percentage in total ${ }^{1}$.

\section{Start-up business in Kosovo - General Characteristics}

Table 2. Registered companies

\begin{tabular}{|l|l|l|l|l|l|}
\hline & Total & Micro & Small & Medium & Large \\
\hline $\mathbf{2 0 1 0}$ & 7,288 & $98 \%$ & $1.72 \%$ & $0.22 \%$ & $0.06 \%$ \\
\hline $\mathbf{2 0 1 1}$ & 7,525 & $98,40 \%$ & $1.38 \%$ & $0.19 \%$ & $0.03 \%$ \\
\hline $\mathbf{2 0 1 2}$ & 9,195 & $98,32 \%$ & $1.46 \%$ & $0.22 \%$ & $0.00 \%$ \\
\hline
\end{tabular}

The total number of new companies registered in 2010 was 7.28282 and less in 2011 at the quota of 7.5253. Most of these start-ups were micro-enterprises.

Table 3.Number of companies per region

\begin{tabular}{|l|l|l|l|l|l|l|l|}
\hline & $\begin{array}{l}\text { Prishti } \\
\text { na }\end{array}$ & Prizren & Ferizaj & Gjilan & Peja & $\begin{array}{l}\text { Gjakov } \\
\text { a }\end{array}$ & $\begin{array}{l}\text { Mitrovi } \\
\text { ca }\end{array}$ \\
\hline $\mathbf{2 0 1 0}$ & $29.5 \%$ & $8.4 \%$ & $7.3 \%$ & $8.63 \%$ & $4.8 \%$ & $4.8 \%$ & $4.2 \%$ \\
\hline $\mathbf{2 0 1 1}$ & $27.6 \%$ & $9.5 \%$ & $8.3 \%$ & $6.49 \%$ & $4.8 \%$ & $3.3 \%$ & $4.4 \%$ \\
\hline $\mathbf{2 0 1 2}$ & $27.6 \%$ & $9.09 \%$ & $7 \%$ & $6.28 \%$ & $5.1 \%$ & $5 \%$ & $4.9 \%$ \\
\hline
\end{tabular}

Geographically, Prishtina has the largest number of new companies, followed by large regional cities, headed by Prizren:

Start-up Support Schemes

1 The Government of Kosovo, Republic of Kosovo, Development Strategy of Small and Medium Enterprises in Kosovo, Prishtinë, 2011. 
A large number of donors, projects, and associations are active (and have been) in the field of Supporting Start-up Businesses in Kosovo. Currently, the following projects provide technical support and sometimes financial assistance to start-ups:

Young Entrepreneurs Program (YEP) / USAID,

Development of Vocational Training and Training Schemes in Companies and Development of Entrepreneurship Skills / (KOSVET 6) EU;

Center for Entrepreneurship and Executive Development (CEED) / SEAF, USAID, FMO SPARK / Center for Business Establishment in Kosovo (BSCK)

Kosovo Innovation Center (ICK) • TAM / BAS (EBRD)

Kosovo SME Promotion Program - KOSME (Swiss \& ADA)

Winners of EU Economic and Regional Development (EURED) grants ${ }^{1}$.

\section{Encourage Women to Enter the Business}

According to local economists, every ninth business in Kosovo is owned by a woman. The sectors in which women are engaged (as owners) are mainly low-value sectors, and not tradable.

Female-owned businesses are also smaller compared to male-owned ones. Thus, female businesses employ, on average, 3.5 workers; while male businesses employ twice that - about 7 workers.

Women businesses, on average, have an annual turnover of no more than 20,000 euros; while for men this average reaches about 50,000 euros per year. Women and men are not equal even in terms of the profit margin they realize in a year.

Thus, while women (always on average) make a profit of $18 \%$, that of men reaches up to $22 \%$. Women are also limited in terms of the diversity of business financing. Therefore, for most women-run businesses (over 55\%) bank lending continues to be the most common form of financing. In Kosovo, 13\% of businesses are owned by women, of which $95 \%$ are micro or small businesses with 1 to 10 employees.

owners also speaks in favor of men. Out of 2,237 enterprises registered in this period, 1,774 of

Based on data from the Kosovo Agency of Statistics (KAS), the enterprise structure by gender of them are with male owners or $79.3 \%$ and 247 of them with female owners or $11 \%$, while 216 enterprises or $9.7 \%$ are with mixed male and female owners.

${ }^{1}$ Helvetas Swiss Intercooperation, Start-up businesses and start-up support services in Kosovo, Prishtinë. 


\section{Municipal Support of Women in Business}

The Municipality of Prizren through its regulation on subsidies as well as the Action Plan for Gender Equality has declared its commitment to gender equality and equal opportunities. The Strategic Objective of the Action Plan on the issue of employment is the economic empowerment and achievement of employment of women in the Municipality of Prizren. While increasing the number of women in initiating and running small businesses, the promotion and development of small businesses are under the objectives of the Action Plan.

In cooperation with the organization 'Help', 43 businesses were supported by equipment or assets worth up to 2,000 euros, where 55\% of the beneficiaries were women, who mainly deal with hairdressing, handicrafts, etc., in which case, the contribution The participant of the Municipality of Prizren in this project was 16,000 euros ${ }^{1}$.

\section{Banks and Support for Women Entrepreneurs in Kosovo}

The seminar "Women in Business" was held in Pristina, organized by TEB Bank JSC, European Bank for Reconstruction and Development (EBRD), and Frankfurt School.

The seminar was opened with a speech by Dren Krypa (Deputy Director of TEB Bank JSC), followed by speeches by Leonora Kusari (Chief Manager, Business Advice-EBRD) and Yllka Brada (Owner of Yllka Brada BI - Fashion Designer).

During his speech, Mr. Krypa emphasized the importance of women's participation in entrepreneurship, the commitment that TEB bank has to entrepreneurship, while he also focused on some of the achievements that the bank has marked in its journey in the program "Women in Business".

"The current portfolio of Women Entrepreneurs in Business stands at around 7 million Euros, of which more than 200,000 Euros are from start-ups. In total, more than 700 clients are credited, and more than 80 of them are Start-Up businesses. "These businesses have come from different sectors and their owners have different backgrounds, qualifications, and areas of expertise", said Krypa.

The Representative of BERZH, Mrs. Kusari presented the program and support offered by the European Bank for Reconstruction and Development for women in business ${ }^{2}$.

\footnotetext{
1 Kosovo Democratic Institute, Supporting women in business on its own initiative- the only solution, Prizren 2017.

2TEB BANK-Kosovo, Workshop for Women in Business, Prishtinë, 2017.
} 


\section{Kosovo Credit Guarantee Fund}

The Kosovo Credit Guarantee Fund is an independent and sustainable institution that issues guarantees to financial institutions to cover the credit risk of micro, small and medium enterprises (NMVM).

FKGK was established in January 2016, based on the Law on the Establishment of the Kosovo Credit Guarantee Fund. The purpose of the FKGK is to support the private sector in Kosovo, by expanding access to finance for NMVMs, thus enabling job creation, increasing local production, improving the trade balance, and advancing opportunities for economic sectors. little served.

The FKGK founding law was initiated by the Ministry of Trade and Industry, and its development was supported by USAID in Kosovo, through the EMPOWER Credit Support Program (ECS). The law entered into force on January 23, $2016^{1}$.

\section{Survey}

\section{With Businessmen Regarding the Challenges of Kosovo Businesses}

In this survey, 77 businessmen from the city of Prizren and the surrounding area were interviewed regarding the challenges they face and their answers are expressed in $\%$ as follows.

\section{Figure 1. Is there a bureaucracy on getting business loans}

\section{IS THERE A BUREAUCRACY ON GETTING BUSINESS LOANS}

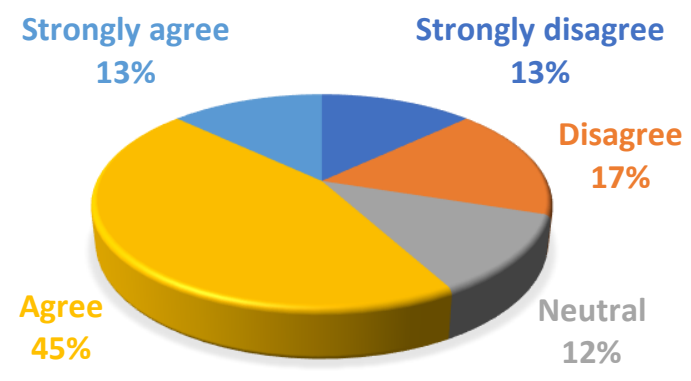

When asked if there is a bureaucracy in obtaining business loans $45 \%$ of respondents agreed and $13 \%$ fully agreed.

Based on the survey results we can say that there is bureaucracy in obtaining business loans. A lot of documentation, procedures are required and there is a lot of bureaucracy.

\footnotetext{
${ }^{1}$ Kosovar Credit Guarantee Fund, Guarantee Financial Institutions, Prishtinë, 2018.
} 
Figure 2. Is there much collateral required by banks for obtaining business loans

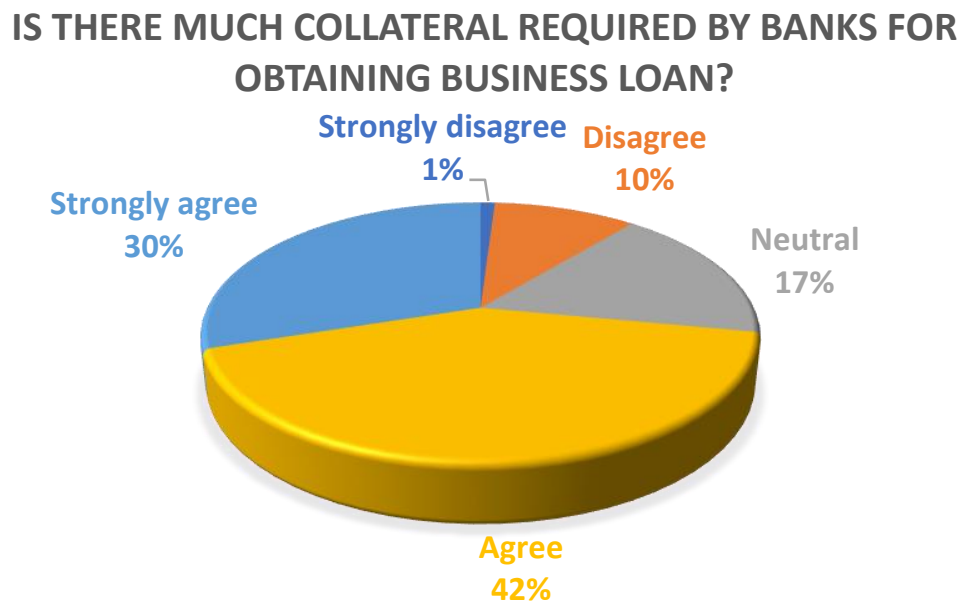

To the question is there much collateral required from banks to obtain a business loan? $42 \%$ of respondents agreed and $30 \%$ fully agreed that a lot of collateral is required.

It can be concluded that banks require a lot of collateral when obtaining loans. Collateral is one of the barriers to business financing. FKGK covers $50 \%$ of the collateral as a relief for financing but the use of these funds has an annual cost of $2.0 \%$ and increases the interest rate $+2.0 \%$ of the existing one.

\section{Figure 3. Does the business have the necessary institutional support}

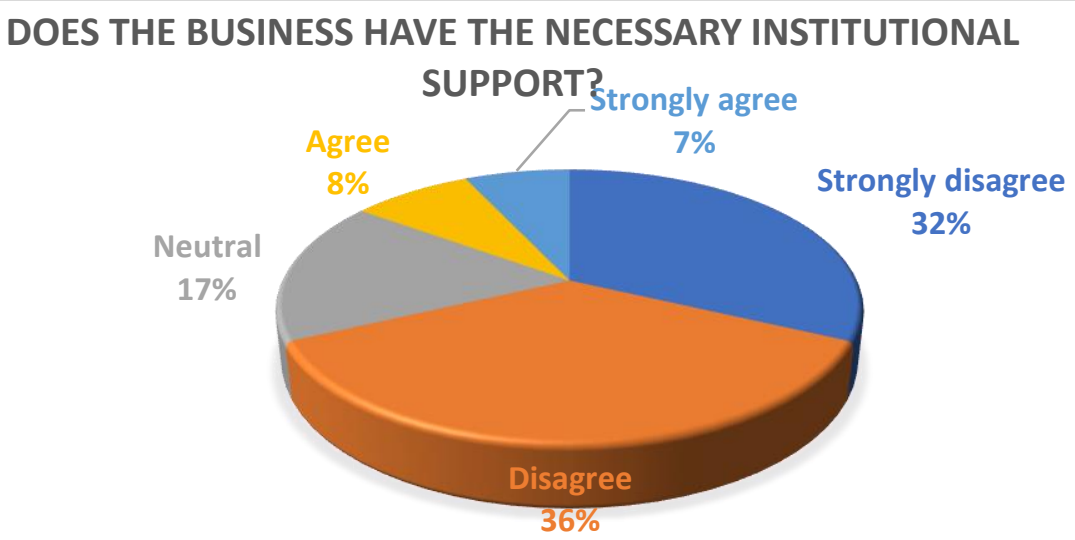

When asked if the business has the necessary institutional support based on the results of the respondents, it turns out that 32\% have completely disagreed and 36\% have disagreed that there is the necessary institutional support. 
Businesses need more support from local institutions to have rapid development of the local economy. Institutional support of businesses will enable the creation of new jobs as well as the growth of the local economy in general.

Figure 4. Do you think that business loans have a short loan repayment period?

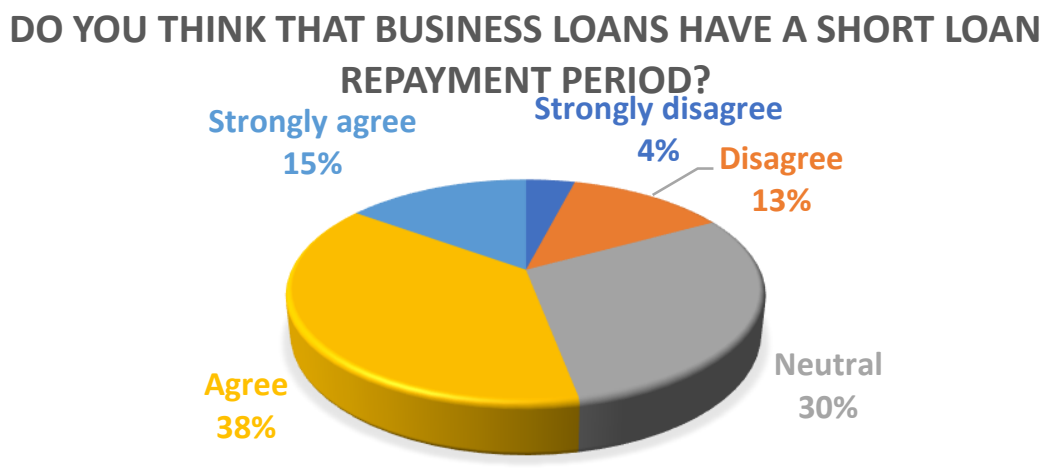

When asked if loans have a short repayment period. 38\% of respondents agree that loans have a short repayment period $15 \%$ of respondents fully agree that loans have a short repayment period.

Loans have a short repayment period to make capital investments in the business must have a longer repayment period and must have a grace period. If we want to have business development and make capital investments, the loan repayment period should be longer.

Figure 5. Are interest rates high on business loans?

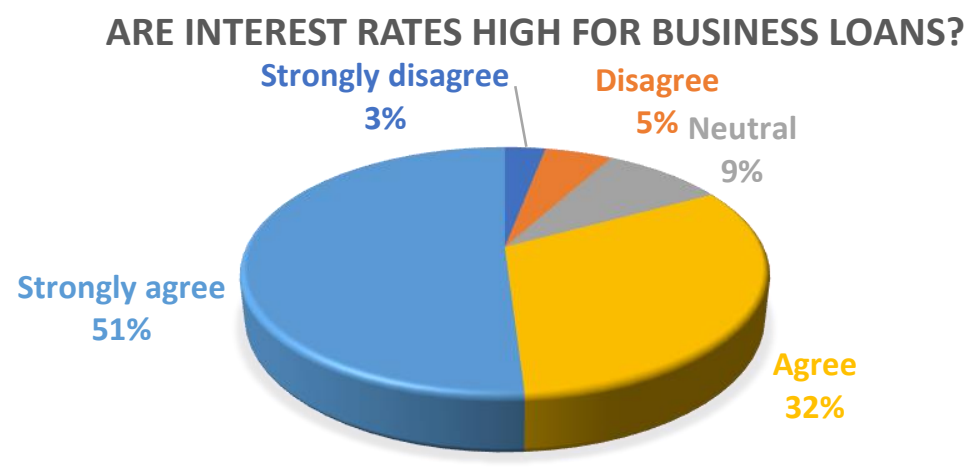


Interest rates in Kosovo are around 7.2\% which are considered high and as such do not stimulate business development. Although we have falling interest rates, they are still high.

Interest rates of $2-3.0 \%$ would be more favorable and would stimulate business development in Kosovo. Developing a development bank and lending interest rates of up to $50 \%$ would stimulate local businesses.

\section{Figure 6. Do you think the informal economy hurts business?}

DO YOU THINK THE INFORMAL ECONOMY HURTS BUSINESS?

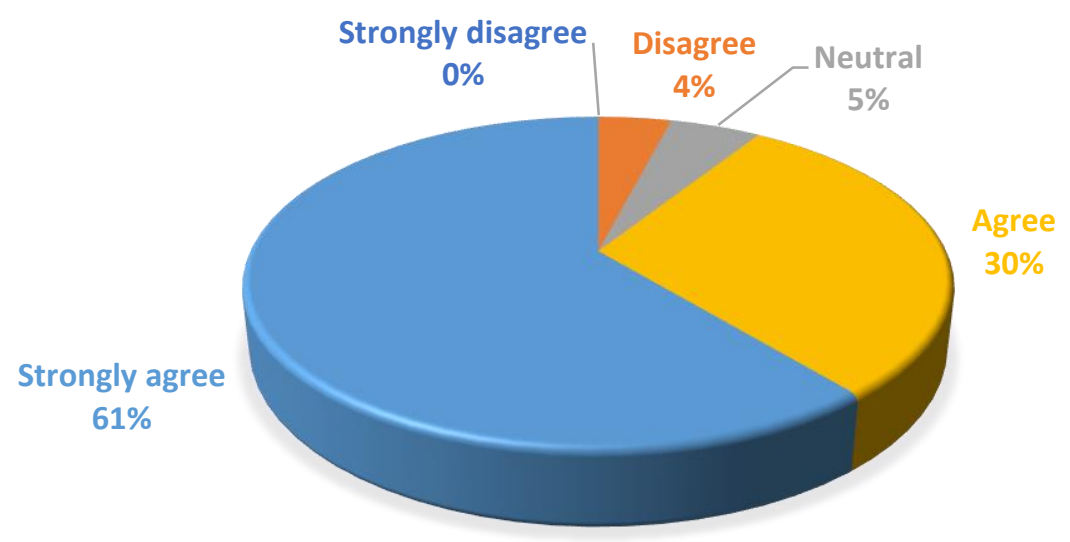

To the question, that the informal economy harms business, the respondents answered as follows: $30 \%$ agree and $61 \%$ fully agree that the informal economy harms business.

The informal economy is expressed in Kosovo and this economy harms the local economy and our businesses. To make the biggest fight of the informal economy by local institutions as well as to make the biggest support of the formal economy. 


\section{Figure 7. Do credit policies stimulate business development?}

\section{DO CREDIT POLICIES STIMULATE BUSINESS DEVELOPMENT?}

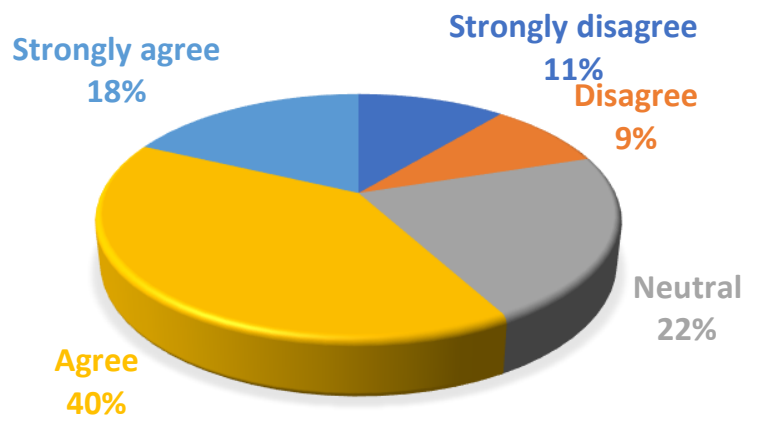

When asked how credit policies affect or stimulate business development $40 \%$ of respondents answered that they agree that credit policies stimulate business while $18 \%$ fully agree.

Genuine credit policies affect the development of agriculture but in Kosovo interest rates are high. Interest rates should reach 2 to $3 \%$ to stimulate business development.

Development banks should be established to support businesses with low-interest rates and long loan repayment terms.

Have a grace period in the early years as businessmen are in the investment period. As well as depreciation plans are with variable payments.

\section{Figure 8. Do you think business taxes are high?}

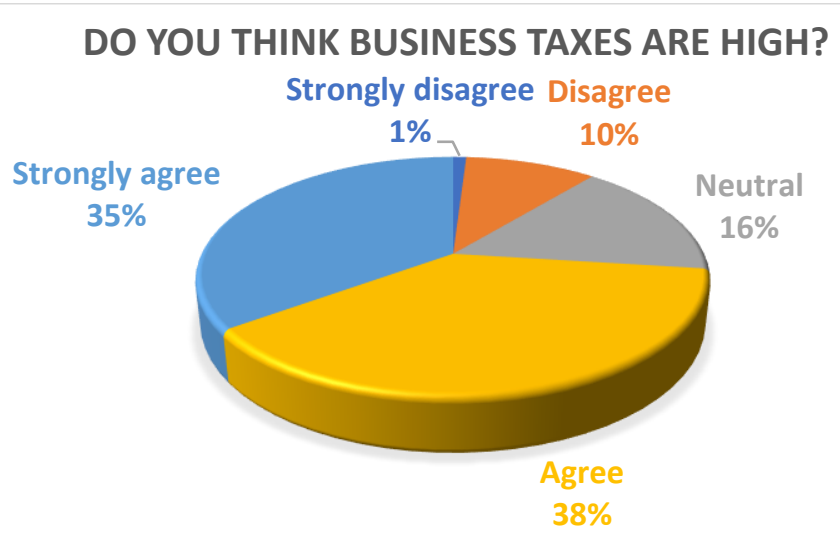

When asked what do you think about whether business taxes are high, 38\% of respondents agreed, and 35\% completely agreed that tax rates are high 
Based on the survey results, we can say that business tax rates are high. The lower the business taxes, the more the business development is stimulated and the economic development in general. Fiscal policies need to be improved to reduce the level of taxes.

\section{Figure 9. Do you think unfair competition hurts business?}

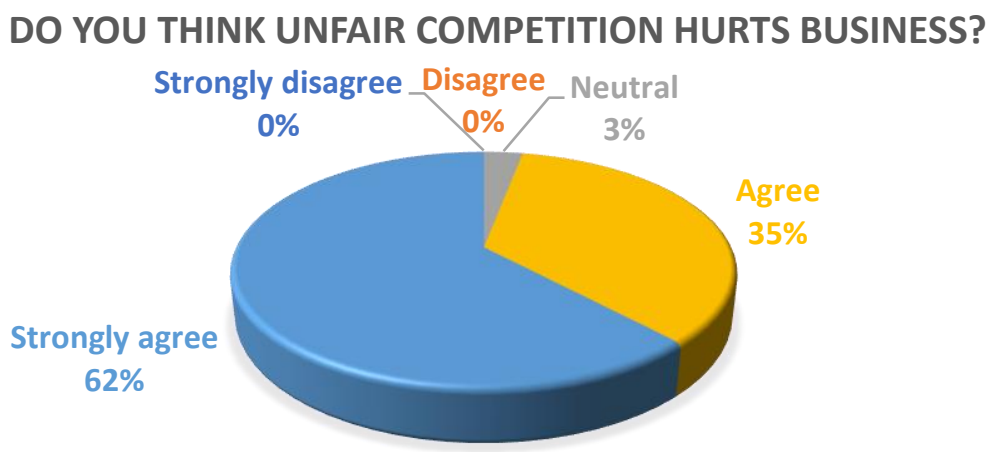

When asked if they think unfair competition harms business, 35\% of respondents agreed, and $62 \%$ completely agreed that unfair competition harms business.

Based on the survey results we can say that unfair competition harms business. Fighting unfair competition would help both businessmen and citizens of the country. Unfair competition hurts our businessmen and makes them unequal in the market.

Poor quality goods harm the business, and the citizen is sold goods at lower prices, and the quality is the lowest.

Figure 10. Is the local entrepreneur stimulated to increase his business activity?

IS THE LOCAL ENTREPRENEUR STIMULATED TO INCREASE HIS BUSINESS ACTIVITY?

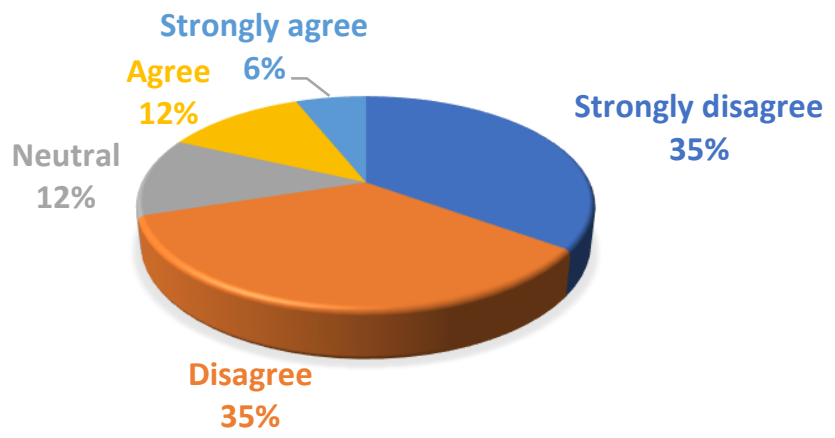


When asked whether the local businessman is stimulated to increase his business activity, $35 \%$ of respondents disagree, and $35 \%$ completely disagree that there is a stimulus to the local businessman.

Based on the result, it is apparent that local businesses need to be stimulated more in business activities. The entry of young people into the business, the stimulation of start-up businesses, and the encouragement of women to enter business should also be stimulated. Government grants, and subsidies, municipal support, EU funds, World Bank, US-Aid, BERZH, and various projects, would enable entrepreneurs to increase their business activity.

\section{Conclusion}

Kosovar businesses face many challenges, including bureaucracy starting with business registration. There is a lot of bureaucracy and nepotism when applying for subsidies, grants and many documents are required.

Many collaterals, many documents, and many procedures are required when applying for a loan. Microbusinesses cannot be financed by banks, for not providing the necessary collateral.

Interest rates are high offered by commercial banks in Kosovo. The loan repayment period is short. Financing of long-term projects is not stimulated.

It does not stimulate the financing of start-up businesses and the investment of businesses for women. Given that, we have a young population. Commercial banks do not finance start-up businesses.

\section{Recommendations}

Credit and fiscal policies are not conducive to business development in Kosovo. Businesses do not have enough institutional support, and taxes are high.

Interest rates to be reduced to $2-3 \%$, on an annual basis, or to be reimbursed, $50 \%$ of the total interest rate. Increase the repayment period of loans (long-term loans) for capital investments. Allow grace periods at the beginning of the investment! As well as have variable payments based on business income.

Reduce bureaucracies when taking loans, reduce the demand for collateral by banks when taking loans. Reduce the business tax rate. Reduce unfair competition and the informal economy that hurts local business. Reduce interest rates as loans are now covered by KGCF funds by $50 \%$, which reduces the risk in case of failure of these loans.

To stimulate start-up businesses, to support projects, especially in the field of informatics. Start-up businesses are not so much supported by banks in Kosovo. Increase women's participation in business through support, because they make up about $13 \%$ of businesses operating in Kosovo. It is intended that female participation in business reach $50 \%$. 
Make greater support of micro-businesses because these businesses can grow and develop and employ a large number of employees. Microbusinesses in Kosovo make up about $98 \%$ of enterprises in Kosovo. Establish a development bank that would support local businesses and create better facilities and conditions for, both local and foreign investors.

To invest in local producers, to stimulate exports, to certify local producers and international quality standard ISSO 9001, HACCAP, as well as other standards in order to penetrate the markets of the region, EU countries as well as in markets of other countries.

\section{References}

[1] Muhamet Ajrullahu, Challenges of doing business in Kosovo, Rajoni Press, Gjilan 2020.

[2] Kosovo Chamber of Commerce, Paving the way for better business in Kosovo, Prishtinë, 2018.

[3] Arbër Berisha, The challenges of opening and maintaining a functioning business, Ekonomia, Prishtinë, 2021.

[4] The Government of Kosovo, Republic of Kosovo Development Strategy of Small and Medium Enterprises in Kosovo, Prishtinë, 2011. fq 17.

[5] Helvetas Swiss Intercorporation, Start-up businesses and start-up support services in Kosovo, Prishtinë, 2014, fq 9.

[6] Kosovo Demokratic Institute, Supporting women in business on its own initiative- the only solution, Prizren 2017, fq 9-10.

[7] TEB Bank-Kosovo, Workshop for women in Business, Prishtinë, 2017.

[8] Kosovar Credit Guarantee Fund, Guarantee Financial Institutions, Prishtinë, 2018. 